Review Article

\title{
Determinants of Smallholder Farmers Market Participation and Outlet Choice Decision of Agricultural Output in Ethiopia: A Review
}

\author{
Sheleme Refera Jebesa \\ Agricultural Economics Research Team, Bako Agricultural Engineering Research Center, Bako, Ethiopia \\ Email address: \\ Shelemerefera2014@gmail.com
}

To cite this article:

Sheleme Refera Jebesa. Determinants of Smallholder Farmers Market Participation and Outlet Choice Decision of Agricultural Output in Ethiopia: A Review. American Journal of Agriculture and Forestry. Vol. 7, No. 4, 2019, pp. 139-145. doi: 10.11648/j.ajaf.20190704.13

Received: June 11, 2019; Accepted: July 24, 2019; Published: August 12, 2019

\begin{abstract}
The majority of farmers in Ethiopia are smallholder farmers. However, smallholder farmers Participation in markets remain low due to range of resource constraints such as capital, inputs and technology and their exposure to risk. Therefore, this paper was aimed to review different literature determinants of smaller holder farmers' market participation and outlet choice decision in Ethiopia based on desk review method. The review reveals that demographic and socio-economic factors, institutional factors, market factors, technological factors, transaction cost and risk were determinants of smallholder farmers' market participation decision in Ethiopia. On other hand, the determinants of smallholder farmers' market outlet decision also reviewed. Accordingly, household characteristics, transaction costs, product characteristics, household asset and trusts on buyers were determinants smallholder farmers' market outlet choice in Ethiopia. Therefore, government and concerned bodies should improve rural infrastructure, smallholder farm productivity through technology, market information, promotion of farmer associations to enhance market participation and outlet choice small holder farmers in Ethiopia.
\end{abstract}

Keywords: Ethiopia, Output, Market Outlet, Market Participation, Smallholders

\section{Introduction}

\subsection{Background}

Ethiopia is one of the Sub-Saharan Africa countries that liberalized its economy and developed Poverty reduction strategies that strengthen market-led strategies for agricultural development and economic growth [6]. It has endowed with abundant agricultural resources and has diverse ecological zones. Its economy is mainly dependent on agriculture. Over $85 \%$ of its population lives in the rural area where crop production and animal husbandry is their main stay. The sectoris counting $35.8 \%$ of GDP and $70 \%$ of foreign exchange earnings. It provides employment for $72.7 \%$ of the population [16].

The majority of farmers in Ethiopia are subsistence smallholders, are known resource constraints such as capital, inputs and technology, heavy dependence on their household labor and their exposure to risk such as reduced yields, crop failure and low prices [18]. However, about 12 million smallholder farming households account for an estimated 95 percent of agricultural production indicating the dominant contribution of smallholder farmers to the overall agricultural production [21]. Ethiopian land is fragmented and majority of the farmers are smallholder that have small size of land holding. The average holding sizes per household and per holder were 1.14 hectare and 1.10 hectare, while the average holding size in all cropped area per household and per holder were 0.95 hectare and 0.92 hectare, respectively [17].

Participation of smallholder Ethiopians' farmers in markets remains low. Limiting constraints faced by smallholder farmers is linked to poor market access, high transaction costs, Poor infrastructure and weak institutions cause transaction costs to rises, which considerably alter production and market-participation decisions [11]. These problems also results in poverty. The important route to reduce poverty in rural areas is to enhance the market participation of smallholder farmers, as this can increase the net returns to 
agricultural production.

The importance of market participation to economic growth and poverty reduction arises from the fact that market participation leads to market-oriented production where the household specializes in the production of those goods for which it holds comparative advantage [35]. Market participation is the ability of an entity to participate in a market efficiently and effectively. It is the transitions by farmers from subsistence farming to a market engagement mode, where by inputs are increasingly purchased and farms outputs sold to traders [34].

The transition from subsistence, or from a lower to a higher level of market participation, is influenced by the ability of farmers to produce products which meet market expectations in terms of quality, standards, and ability to deliver products on time for sale at a viable price. [40] Also defined market participation as the proportion of agricultural production that is marketed and can be measured along a continuum from zero (total subsistence-oriented production) to unity ( $100 \%$ of production is sold). Market participation has motivated the farmers to move from subsistence farming to commercial farming.

The transformation of subsistence agricultural production into a commercially oriented system requires two essential dynamics: 1) efficient market services for timely delivery of quality inputs to farmers at competitive prices, 2) transparent output markets that provide signals to the farmers, allowing them to make informed decisions on what to produce and at what quality standards, as well as where and when to sell their outputs to be promoted and which markets to focus on [9].

According to [52], the contribution of smallholder farmers to reducing poverty and hunger in low-income countries depends on sustainable access to and participating in markets. Marketing plays an important role in agricultural commercialization and accessibility of the market for commodities allows specialization of production, which in turn increases production and productivity. Therefore, Sustainable success in agricultural growth depends not only on achieving agricultural productivity and household food consumption but also critically depends on increasing better market access and expansion of market opportunities. Proper functioning market will only occur when enough markets and efficient market outlets exist for the sale of produced output and no single entity can individually influence the price [51].

On other hand, farmers' choice of market outlet is a very important aspect in market participation decision. Market outlet choice is the farmers' decision on where to or not to sell their farm produces [25]. Smallholder farmers have alternative market outlet for selling their agricultural produce. These outlets offer different prices and sales services, which determine farmers' choices market outlet their produce. Choosing of market outlet by smallholder farmers plays an important role in improving their incomes. They choose to market his/her crops through a specific channel if the expected utility gained by selling through selected channel is greater than all the other channels. In order to maximize the benefits that they may earn, farmers have to make appropriate decisions as to where they should sell their product. The choice of marketing outlets by the individual farmers helps them in exploring the options from which they derive maximum satisfaction [54]. Therefore, reviewing a literature on determinant of smallholder market participation and outlet choice decision is very important in order to verify the major factors and generate information on decisions of market participation and outlet choice in Ethiopia.

\subsection{Objective of Review}

1. To review different literature on determinants of smallholder farmers market participation decision in Ethiopia.

2. To review different literature determinants of smallholder farmers market outlet choice in Ethiopia.

\subsection{Significance of Review}

This review identifies and provides information on determinants of smallholder farmers' market participation decision and outlet choice in Ethiopia. The review also helps farmers and policy maker to design appropriate technologies and information transfer systems for market participation and outlet choice of agricultural products based on the idea from this review.

\subsection{Methodology of Review}

This paper was reviewed by referring different studies, published documents in different international journals based on desk review method.

\section{Discussion}

In this chapter, key concept used in the review has been defined. The chapter also presents reviews literature on the determinants of smallholder market participation decision and outlet choice in Ethiopia.

\subsection{Definition and Basic Concepts}

Smallholder farmers: Smallholder farmers are defined as the basis of land and livestock holdings, cultivate less than two hectares of land and own only few herds of livestock [42].

Market: a point or a place within which price-making force operates and exchanges of title tend to be accompanied by the actual movement of the goods and services being transacted [10].

Market participation: Market participation entails farmers being able to buy inputs in the input market or being able to sell their output in the output market [28]. It also defined as any market related activity which promotes the sale of produce [30].

Market outlets: are the buyers through which the farmers sell their farm product [13]. 


\subsection{Importance of Smallholder Farmers'Market Participation}

Market participation by farmer plays a crucial role for deriving benefit such as income and rural employment in the farming. The rural employment derives from market participation includes sorting, grading, transportation among other activities. Market participation has motivated the farmers to move from subsistence farming to commercial farming. Commercial farming increases farms' output, hence enabling the farmer to earn more income. [29] Noted that farmers' market participation is very vital for sustaining economic growth, food security and poverty alleviation. Most farmers who participated in the market tend to be food secure because the income they derives from the sale of their output has enabled them to purchase the staple food.

Economic liberalization has given opportunities for smallholder farmers to diversify their products and take their surplus to nearby markets [8]. Removing trade barriers and discouraging local monopoly has helped smallholder farmers to choose their markets for both inputs and harvested products [12]. In summary, marketing plays a crucial role in meeting the overall goal of food security, poverty alleviation and sustainable agriculture, by integrating subsistence farmers into the inputs and outputs market of agricultural products [3].

\subsection{Determinants of Smallholder Farmers Market Participation Decision}

Market participation is determined by external and internal factors [39]. The internal factors are barriers which relate to the failure by farmers to meet market expectations due to lack of physical asset, financial assets and human assets. Factors like smallholder resource endowments including land and other natural capital, labor, physical capital, human capital and so on are household specific and considered to be internal determinants [33]. The external ones are factors beyond the smallholders control like technological change and development of new infrastructure.

Smallholder farmers also frequently lack commercial information, physical infrastructure is poor causing high transaction costs, and remoteness increases costs and reduces competition [34]. The determinants of smallholder farmers' market participation decision include; demographic and socio-economic factors, institutional factors, market factors, technological factors, transaction cost and risk.

\subsubsection{Demographic and Socio-economic Factors}

Demographic and Socio-economic factors are factors that influence the social and economic wellbeing of an individual turn to determine small holder market participation [25]. Demographic and social-economic factors are includes: age, gender, education, experience, household size, land size, livestock ownership and off-farm income. [48] Conducted study on determinants of kocho and bulla market participation decision and intensity of participation at farm level using Hackman selection model (two-step) in
Doyogena district, southern Ethiopia. The result revealed that, age of the household head, number of livestock owned and area under Enset cultivation were positively where family size was negatively affect kocho and bulla market participation.

NuriLefebo Conducted a study on determinants of market participation among kocho producers in Hadiya Zone [36]. They adopted Heckman selection model to indicate determinants of farmers' participation decision and extent of participation in kocho market. They found age of the household head, sex of the household head, livestock ownership, off-farm income and labor as statistically significant factors affecting kocho farmers' market participation decision. [26] Investigated study on determinants of smallholder market participation among banana growers in bench Maji Zone, Southwest Ethiopia. They used the Heckman selection model (two-step) to identify the factors affecting market participation decision of households. Their result revealed that age, household size, fruit income, land holding, livestock (TLU) were significantly affect smallholder market participation among banana growers.

\subsubsection{Institutional Factors}

Institutional factors are factors that govern production and transaction activities of farmers and turns to influence market participation. Institutional factors are includes credit access, infrastructure, member ship in the group and extension service has an influence on market participation. Amount of credit taken increases the probability of household's market participation. This might be due to higher amount of credit eases liquidity constraints of households that contributes to market orientation.

In addition, it means higher capital to invest in livestock, in higher yielding crops, in seasonal inputs that boost yields, in purchase of fertilizer and improved seeds and invest in improved technologies [24]. Membership to the group has both positive and negative impact on market participants. It positively impacts on market participation because it increases households' access to information vital to production and marketing decisions. On the other hand, it can negatively impact market participation in case disagreement emerges among group members, distorting marketing decision [38]. Extension service has impact positively on market participation because it is through extension services that farmers are able to acquire better skill and knowledge on marketing As a result, institutional factors like infrastructure and access to extension service should be given attention due to their role in market participation [4].

\subsubsection{Market Factors}

Market factors are any external factors that affect the demand for good or the price of a good. According to [34] Supply-side and demand-side constraints are limit market participation by smallholder farmers. supply-side constraints includes physical constraints such as poor roads and infrastructure, lack of storage facilities, poor communication that adversely affect their market participation and capacity 
constraints such as lack of credit and financial services that inhibit them from improving their productivity, lack of access to inputs and other agricultural technologies, lack of organizational support, lack of skills and knowledge on new technology that would increase their production, poor knowledge of market. A demand-side constraint includes political constraints such as domestic policies that disfavor trade as requiring trade licensing. Market factors have been found to positively and negatively influence market participation. [29] Stated that availability of market information boosts confidence of household who are willing to participate in the market. Poor access to market information results in information-related problem, namely moral hazard and adverse selection which in turn increase transaction costs and hence discourages participation in the market by some farmers [44].

According to [54], conduct their study on determinants of smallholder farmers' participation in potato market in Kofele district, Oromia Region, Ethiopia. They found that potato market price and access to market information positively affects farmers' participation decision. Since farmers are more responsive to higher prices because they got higher incomes from their produces and Market information is a vital instrument during marketing because it informs the farmers about marketing conditions. Farmers who have price information prior to marketing tend to sell more of their produce than those without. They suggest that effort should be made to deliver proper and adequate market information through strengthening market information delivery network and also link farmers' cooperatives/groups with proper sources of market information to enhance potato farmers' regular access to information on market dynamics.

\subsubsection{Technological Factors}

The importance of resource-saving and yield-enhancing technological innovations and their adoption by farmers are unquestionable in the smallholder market participation process [49]. Households operating with agricultural technologies were participating in markets by affecting his/her productivity. Increasing the productivity of horticultural crops per unit area of land through promoting and delivering technology packages to smallholders that would increase productivity and enables them to link up with crops output market would be a better alternative for smallholder market participation [6].

\subsubsection{Risk}

Risk and market participation are interlinked [20]. Agriculture is a risky enterprise, as most agricultural activities are subject to a wide range of risks. Production risk, price risk, financial risk and institutional risk affect market participation [50]. Risk perceptions and management strategies are strongly associated with market participation. Key strategies included monitoring market prices, diversifying sales channels and crop diversifications were more important for subsistence-oriented farmers [46].

\subsubsection{Transaction Costs}

Transaction costs refer to costs incurred when looking for a trading partner, negotiate with them, making agreement and enforce it. Transaction costs could be in terms of money spent or the opportunity cost of time spent. Transactions in markets are not frictionless and without cost. Smallholder farmers to fully participate in markets they must also be able to meet both observable and unobservable transaction costs. The observable transaction cost is physical marketing costs such as transport, handling, packaging, and storage. Unobservable transaction costs include cost of information search, bargaining, screening, monitoring agent and coordination, and contract enforcement [34]. [5] Argue that transaction costs significantly hinder market participation whereas better market information stimulates it. Access to markets and roads are expected to reduce marketing costs, thus encourage market participation. [15] they study on determinants of market participation and financial profitability of smallholder dairy farming in BakoTibe, West Showa, Ethiopia. They found household market participation is affected by transaction cost represented by distance to market and urban center. Based on finding they suggested reducing transaction cost and adequate marketing link should be established between rural producers and urban consumers through institutional arrangement as cooperative.

\subsection{Determinants of Smallholder Farmers Market Outlet Choice Decision}

Choice of market outlet is the farmers decision on where to or not to sell their farm produces. Before choosing a market outlet, farmers consider the costs associated with transportation, profits, level of trust among the available channels and familiarity of the markets ([54]. The farmer is likely to choose the one which gives higher benefits and it has great impact on household income [43]. Market outlet choices are a household-specific decision and several drivers have to be considered as a basis for such decision. Smallholder farmers' decision to choose different market outlets can be affected by household characteristics, resource endowments and access to different market outlets, prices, and transportation cost [14, 33, 43], and they confirm that lack of market knowledge or difficulties in accessing markets that are more rewarding makes smallholder farmers to transact their produce through an outlet offering low price.

Producers choose their marketing plans and assess outside options that are available before participating in any market outlet. The farm income earned from sales depends on the farmer's experience in producing and selling farm products, the farmer's comparative advantage in bargaining and marketing skills combined with differences in the regional development and accessibility of outlets for farm products. Several studies have been carried out to identify factors influencing farmers' choice of market outlet. These include household characteristics, transaction costs, product characteristics, household asset and trusts on buyers are affecting farmers' market outlet choice. 


\subsubsection{Household Characteristics}

Household characteristics such as age, education, household size and gender could influence a household's market channel choice by smallholder farmers in Ethiopia. [1], investigate the study on determinants of commercialization and market outlet choices of teff smallholder farmers in Dendi district of Oromia, central Ethiopia. He used probit (MVP) model to identify factors affecting market outlet choice of tef. The multivariate probit model result indicated that educational level and household size significantly influenced teff producers' choice of alternative market outlets. [37] employed multivariate probit model to identify factors affecting market outlet choice of groundnut producers in Digga district of Oromia, Ethiopia. The multivariate probit model results revealed that educational level affect the choice of appropriate market outlets of producers.

\subsubsection{Transaction Costs}

In addition to household characteristics transaction costs could influence market outlet choice. [47] used multivariate probit model to identify factors affecting market outlet choice of smallholder mango producers in Boloso Bombe district, Southern Ethiopia. Their results from multivariate probit model indicated that variables such distance to the market, proxy for transaction cost determined the decision of choice of wholesaler, collector, retailer and consumer market outlets. As the longer the distance the higher the transport cost and the less likely for the farmer to sell through that channel. [53] Studied the market channel choice decision in the Ethiopian banana markets. They found that transaction costs in the form of information costs, negotiation costs as well as monitoring costs have significant impact on market channel choice by banana smallholder farmers.

\subsubsection{Product Characteristics}

Product characteristics such as output price and perish ability of products have an influence on the choice of marketing channel. A higher price provides an incentive to the selling. Perishable goods, such as, vegetables, milk, fruits etc. can employ shorter channels to minimize the risk of damage. Non-perishable goods such as cereal and pulse crops can be stored for quite a long time if they properly treated [23, 1] Used multivariate probit model to identify determinants of Potato market outlet choices in Ejere district of West shewa zone, Ethiopia. The result of MVP model indicated that quantity of potato sold and selling price of potato significantly influence potato producers choosing of market outlets for their produce.

In analysis of wheat value chain in Sinana district, Bale zone, Oromia Region, Ethiopia. He used Multinomial logistic regression to analyze factors affecting choice of wheat marketing outlets. The study pointed out own price of the commodity significantly affect market outlet choice [45]. Used multinomial logistic model in analyzing determinants of market outlet choice and livelihood outcomes of coffee producing farmers in LaloAssabi district, Ethiopia. The result of the model shows that quantity of coffee sold negatively affected the choice of consumer outlet [32].

\subsubsection{Household Assets}

Household asset is an aggregate amount of assets owned by households influence market outlet choice. [1] Investigate the study on determinants of commercialization and market outlet choices of teff Smallholder farmers in Dendi district of Oromia, central Ethiopia. He used multivariate probit model to identify factors affecting market outlet choice of teff. The multivariate probit model result indicated that livestock owned, equines owned, land under teff significantly influenced teff producers' choice of alternative market outlets. [7] found out that factors such as farm size, proportion of off-farm income to total income affected market channel choice among smallholder coffee farmers in Ethiopia. [53] Studied the market channel choice decision in the Ethiopian banana markets. They found that farm size allocated to banana has significant impact on the proportion of banana sold to wholesale traders. This is due to the fact that large farm sizes mean more bargaining power to farmers in dealing with wholesale traders.

\subsubsection{Trust on Buyers}

Trust defined as expectations that managers of firms adopt about the future behavior of their exchange partners [41]. Trust also encourages farmers and buyers to make relationship-specific investments, which in turn enhances productivity in the exchange relationship without fear of opportunism [19]. Previous studies [2, 53] found that trust have a significant influence on marketing channel selection. According to them farmers who have high trust in buyers are likely to spend less time screening their transacting partners or following up on payments and deliver their product to this outlet.

\section{Conclusions}

Agriculture is main economic pillars of the Ethiopian economy and the economic growth of the country is highly dependent on the success of the agriculture sector. Sustainable success in agricultural growth depends not only on achieving agricultural productivity and household food consumption but also critically depends on increasing better market access and expansion of market opportunities.

The importance of market participation to economic growth and poverty reduction arises from the fact that market participation leads to market-oriented production where the household specializes in the production of those goods for which it holds comparative advantage. Market participation has motivated the smallholder farmers to move from subsistence farming to commercial farming. This review reveals that demographic and socio-economic factor, institutional factors, market factors, technological factors, transaction cost and risk are factors are determine small holder farmers' market participation decision in Ethiopia.

On other hand, market outlet choice is a very important aspect in market participation decision. Smallholder farmers have alternative market outlet for selling their agricultural 
produce. These market outlets offer different prices, which determine farmers' choices of the channel and impact on household income. To derive maximum satisfaction and generate higher income smallholder farmers choice market outlet where they should sell their products. They choose to market his/her crops through a specific channel if the expected utility gained by selling through selected market outlet is greater than the other entire market outlet. However, the review reveals the determinants market outlet choice decision of smallholder farmers includes household characteristics, product characteristics, transaction costs, household assets and trusts on buyers in Ethiopia. Therefore, government should improve rural infrastructure, smallholder farm productivity through technology, market information, promotion of farmer associations to enhance market participation and outlet choice by small holder farmers in Ethiopia.

\section{References}

[1] Addisu Getahun. 2018. Determinants of commercialization and market outlet choices of tef: the case of smallholder farmers in Dendi district of Oromia, Central Ethiopia. MSc Thesis, Haramaya University, Haramaya, Ethiopia.

[2] Addisu Hailu. 2016. Value chain analysis of vegetables: The case of Ejere district, West Shoa Zone, Oromia region, Ethiopia. MSc Thesis, Haramaya University, Haramaya, Ethiopia.

[3] Adenegan, K., Odepoju, A. and Nwauwa L. 2012. Determinants of market participation of maize farmers in rural osumstate of Nigeria. Depertment of agricultural economics of Ibadan, Nigeria. International Journal of Economics and Rural Development 5 (1): 36-65.

[4] Afework Hagos and Endrias Geta. 2016. Review on smallholder agriculture commercialization in Ethiopia: What are the driving factors to focused on? Journal of Development and Agricultural Economics Vol. 8 (4).

[5] Alene, D. A., V. M. Manyong, G. Omanya, H. D., Mignouna, M., and Odhiambo. G. D. 2008. Smallholder marketed surplus and input use under transactions costs: maize supply and fertilizer demand in Kenya. Food Policy 32 (4): 318-328.

[6] Aman Tufa, Adam Bekele and Lemma Zemedu. 2013. Determinants of smallholder commercialization of horticultural crops in Gemechis district, west Hararghe zone, Ethiopia. African Journal of Agricultural Research, Vol. 9 (3).

[7] Anteneh, A., Muradian, R. and Ruben, R. 2011. Factors affecting coffee farmers market outlet choice. The case of Sidama Zone, Ethiopia. Paper presented International Conference on Economics and Management of Networks, Limassol, Cyprus, December 1-3, 2011.

[8] Asfaw, S., Shiferaw B., Simtowe F., Muricho, G., Abate T. and Ferede, S. 2010. Socio-economic assessment of legume production, farmer technology choice, market linkages, Institutions and poverty in rural Ethiopia.

[9] ATA (Agricultural Transformation Agency). 2017. Market service, the agricultural transformation agency Ethiopia sustained development to end poverty (PASDEP). Addis Ababa.
[10] Backman, T. N. and Davidson, W. R. 1962. Marketing principle. The ronal Presses Co., New York. pp. 3-24.

[11] Barrett C. B. 2008. Smallholder market participation: Concepts and evidence from Eastern and Southern Africa. Food Policy 33 (4): 299-317.

[12] Bekele Shiferaw, Obare. A, Muricho G. and Silim. S. 2009. Leveraging institutions for collective action to improvement for small holder producers in less favored areas. African Journal of Agriculture and Resource Economics, 3: 1-18.

[13] Benard O. 2015. Determinants of smallholder farmer market participation; a case study of rice marketing in ahero irrigation schemein Kenya. M.Sc Thesis, Egerton University.

[14] Berhanu, K., Derek, B., Kindie, G. and Belay, K.2013. Factors affecting milk market outlet choices in Wolaita Zone, Ethiopia. African Journal of Agricultural Marketing 1 (2): 024-031.

[15] Bultossa and Adeba.2016. Determinants of market participation and financial profitability of smallholder dairy farming in Bako Tibe, West Showa, Ethiopia.

[16] CIA (Central Intelligence Agency).2018. World fact book. Ethiopian economy Profile. https://www.indexmundi.com/ethiopia/economy_profile.html.

[17] CSA (Central statistical agency). 2015. The federal democratic republic of Ethiopia central statistical agency key finding agricultural sample surveys.

[18] Diao, X., Alemayehu, S. and Pratt, A. N. 2010. Economic importance of agriculture for sustainable development and poverty reduction: the case study of Ethiopia. OECD project report on Global report on Agriculture, 29-30 November 2010. Policies for agricultural development, poverty reduction and food security. Paris, France.

[19] Dyer, J. H. 1997. Effective interfirm collaboration: how firms minimize transaction costs and maximize transaction value. Strategic Management Journal 18: 535-556.

[20] Ellis, F. 1993. Peasant Economics: Farm Households and Agrarian Development. Cambridge: Cambridge University Press. $3^{\text {rd }}$ edition.

[21] FAO (Food and Agriculture Organization). 2018. Ethiopiaat glance.

[22] http://www.fao.org/ethiopia/fao-in-ethiopia/ethiopia-at-a-glanc e/en/.

[23] Frank, E.2014. Market participation, channel choice and impacts on household welfare: the case of smallholder farmers in Tanzania. PhD dissertation University of KwaZulu-Natal Pietermaritzburg.

[24] Gabriel Temesgen. 2014. Small scale irrigation and agricultural commercialization in Tigray Global Journal of commerce and management perspective volume 3 (2).

[25] Geoffrey, S. G. 2015. Factors influencing the choice of marketing outlets among small-scale pineapple farmers in Kericho country. Egerton University, Kenya.

[26] Getahun Kassa, Eskinder Yigezu and DesalegnAlemayehu.2017. Determinants of smallholder market participation among banana growers in bench Maji Zone, Southwest Ethiopia. International Journal of Agricultural Policy and Research 5 (11): 169-177. 
[27] Gindi, A. A., Adeshina, B. A. and Yahaya, K. 2014. Marketing of onion in Aliero local government area, Kebbi state Nigeria. International Journal of Agricultural Science and Veterinary Medicine, 2 (4): 12-19.

[28] Jagwe, J. N. 2011. Impact of transaction costs on the participation of smallholder farmers and intermediaries in the banana markets of Burundi, Democratic Republic of Congo and Rwanda. A PhD Thesis (Agricultural Economics) submitted to the University of Pretoria.

[29] Jari, B. 2009. Institutional and technical factors influencing agricultural marketing channel choices amongst smallholder and emerging farmers in the Kat river valley Master of Science in Agriculture (Agricultural Economics) Faculty of Science and Agriculture University of Fort Hare.

[30] Key, N., Sadoulet, E. and DeJanvry, A. 2000. Transactions costs and agricultural household supply response. American Journal of Agricultural Economics 88 (2): 245-259.

[31] Komarek, A. 2010. The determinants of banana market commercialization in Western Uganda. African Journal of Agricultural Research 5 (9): 775-784.

[32] Mekonin Abera. 2015. Determinants of market outlet choice and livelihood outcomes of coffee producing farmers: The case of Laloassabiworeda, Oromiya, Ethiopia. MSc Thesis, Haramaya University, Haramaya, Ethiopia.

[33] Moti Jaleta and Berhanu Gebremedhin. 2012. Interdependence of smallholders' net market positions in mixed crop-livestock systems of Ethiopian highlands. Journal of Development and Agricultural Economics 4 (7): 199-209.

[34] Nigel, P. 2017. Smallholder agriculture and market Participation. Published by food and agriculture organization of the United Nations and Practical Action Publishing.

[35] Njeri and Kim (2016). Review of smallholder market participation in Kenya: Barriers and determinants. African Journal of Science and Resource (5) 3: 50-56.

[36] NuriLefebo.2016. Value chain analysis of Ensetin Hadiya zone, Southern Ethiopia. $\mathrm{PhD}$ dissertation, Harmaya University, Haramaya, Ethiopia.

[37] Oliyad Sori, Mengistu Ketema and Mohammed Aman. 2017. Factors affecting market outlet choice of groundnut producers in Digga district of Oromia State, Ethiopia. Journal of Economics and Sustainable Development 8 (17): 61-68.

[38] Olwande, J. and Mathenge, M. (2012). Market Participation among the poor rural household in Kenya. Tegemeo institute, Egerton University, Kenya. Selected Paper Prepared for Presentation at the International Association of Agricultural Economists (IAAE) Triennial Conference, Foz do Iguaçu, Brazil, 18-24 August.

[39] Osmani, G. A. and Hossain, E.2015. Market participation decision of small holder farmers and its determinants in Bandagladesh. Review Articles. Economics of Agriculture 1: 165-167.

[40] Pingali, P. 1997. From subsistence to commercial production system: The transformation of Asian agriculture. American Journal of Agricultural Economics 79 (2): 628-634.

[41] Rademakers, M. F. L. 2000. Agents of trust: business associations in agri-food supply systems. International Food and Agribusiness Management Review 3 (2): 139-153.

[42] Salami, A., Kamara, A. B. and Brixiova, Z. 2010. Smallholder agriculture in East Africa: Trends, Constraints and Opportunities. Working Papers Series No.105. Africa Development Bank, Tunis, Tunisia.

[43] Shewaye, A. 2016. Econometric analysis of factors affecting haricot bean market outlet choices in Misrak Badawacho District, Ethiopia. International Journal of Research Studies in Agricultural Sciences 2 (9): 6-12.

[44] Shiferew, B. A., Obare. G., Muricho, G., Silim. S. 2009. Leveraging institutions for collective action to improve market for smallholder producers in less-favored areas. African Journal of Agricultural and Resource Economics 3: 1-18.

[45] Sultan Usman.2016. Analysis of wheat value Chain: The case of Sinana district, Bale Zone, Oromia Region, Ethiopia. MSc Thesis, Haramaya University, Haramaya, Ethiopia.

[46] Suthathip, R., Thomas, B., Pepijn, S. and Chiristian, G. 2016. Agricultural commercialization: Risk perceptions, risk management and the role of pesticides in Thailand.

[47] Takele Honja, EndriasGeta and AmsaluMitiku.2017. Determinants of intensity of market participation of smallholder mango producers: The case of Boloso Bombe Woreda, Wolaita Zone, Southern Ethiopia. Journal of Marketing and Consumer Research. An International Journal Peer-reviewed. ISSN 2422-8451. Volume: 32, 56-63.

[48] TessemaErchafo.2017. Market chain analysis of Enset products: the case of Doyogena district, southern Ethiopia. M.Sc. Thesis, Haramaya University, Haramaya, Ethiopia.

[49] Von Braun, J. Bouis, H. and Kennedy, E. 1994. Agricultural commercialization, economic development and nutrition. International Food Policy research Institute.

[50] USDA (United States Department of Agriculture). 2018. Risk in Agriculture.

[51] Wickramasighe, U., and K. Weinberger. 2013. Smallholder market participation and production specialization: Evolution of thinking, issues and policies. CAPSA Working Paper No. 107.

[52] Wiggins, S. and Keats, S. 2013. Leaping and Learning: Linking smallholders to markets in Africa. London, Agriculture for Impact, Imperial College and Overseas Development Institute.

[53] Woldie, G., and A. Nuppenau. 2009. Channel choice decision in the Ethiopian banana markets: A transaction cost economics perspective. Journal of economic theory 3 (4): 80-90.

[54] Yassin Esmael, Adam Bekele and MengistuKetema.2016. Determinants of smallholder farmers participation decision in potato market in Kofele District, Oromia Region, Ethiopia. 